IRA-International Journal of Management \& Social Sciences

ISSN 2455-2267; Vol.05, Issue 03 (2016)

Pg. no. 455-466

Institute of Research Advances

http://research-advances.org/index.php/RAJMSS

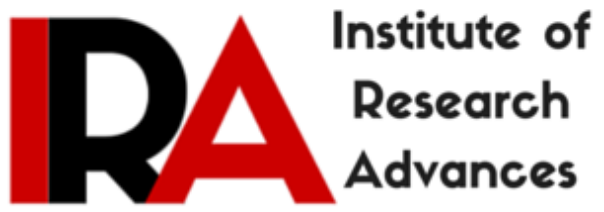

\title{
Glass Ceiling- A Silent Barrier for Women in Highly Advanced and Humanistic Society
}

\author{
Sonia Delrose Noronha ${ }^{1,2}$ and Dr. P. S. Aithal ${ }^{2}$ \\ ${ }^{1}$ Research Scholar, Dept. of Management, Rayalaseema University, \\ Kurnool -518007, Andhra Pradesh, India. \\ ${ }^{2}$ Srinivas Institute of Management Studies, Pandeshwar, \\ Mangaluru -575 001, India.
}

Type of Review: Peer Reviewed.

DOI: http://dx.doi.org/10.21013/jmss.v5.n3.p9

\section{How to cite this paper:}

Noronha, S., \& Aithal, P. (2016). Glass Ceiling- A Silent Barrier for Women in Highly Advanced and Humanistic Society. IRA-International Journal of Management \& Social Sciences (ISSN 2455-2267), 5(3), 455-466. doi:http://dx.doi.org/10.21013/jmss.v5.n3.p9

(C) Institute of Research Advances

\section{(c) EY-NC}

This work is licensed under a Creative Commons Attribution-Non Commercial 4.0 International License subject to proper citation to the publication source of the work.

Disclaimer: The scholarly papers as reviewed and published by the Institute of Research Advances (IRA) are the views and opinions of their respective authors and are not the views or opinions of the IRA. The IRA disclaims of any harm or loss caused due to the published content to any party. 


\section{ABSTRACT}

Indian society in the present scenario is considered to be highly competitive, advanced and techno-friendly enhancing the talents and career growth of both men and women. This educated society has also created awareness for gender equity. Moreover, this advancement has also provided ample opportunities for women to occupy equal positions as men. Since many decades women have made their presence felt in almost all positions in different organizations. Though we find enough number of women occupying many positions it is doubtful about women occupying the executive positions where decision making plays a major role. Along with work life balance and traditions, there is an invisible barrier that acts as a challenge for women influencing their advancement. One can silently observe a glass ceiling creating a barrier for women to optimize their capacities to the fullest. Here arises the need to investigate the presence of the invisible glass ceiling for women and its impact on their career advancement. For the development of a nation, politics plays a vital role. Politicians being the representatives of the people help people solve their problems by making policies and amend the existing laws. Here the participation of women as public servants is equally important. This study hence tries to analyze if there exist any glass ceiling in Indian political scenario and also tries to find the conditions required for women to obtain such positions. The study will be exploratory in nature based on a comparative analysis of the data gathered from various online sources.

Key-words: Glass ceiling, Career advancement, Optimize, gender equity, ventures.

\section{Introduction}

Glass ceiling includes various barriers that prevent the chances of qualified skilled people progressing higher in an organization. Even though there are many women in management position the number of women in the top level positions are few [1]. This kind of ceiling is not desirable as it not only hiders the individual in making use of their potential to the fullest but also hampers the national growth. Country like India that is in the verge of shinning as a super power needs to utilize the expertise of its citizens. India is rich in population and to add on to it, the population is skilled and knowledgeable, but the invisible glass ceiling creates the undesirable barrier. Traditions and preconceived notion or prejudice towards women is the reason that prevents the women from accessing the top positions [2]. This is not a clear concept as the reasons for this barrier varies from situation to situation and from organization to organization. The term 'Glass ceiling' gained popularity in the 1980s.It was pioneered in a book, "The Working Woman Report, by Gay Bryant in 1984. It was later used in an article on a wall street journal on barriers to women in high corporate positions [3]. The term glass ceiling refers to an artificial barrier based on attitudinal or organizational bias that prevents qualified women and other minorities from advancing upward into senior management level positions or situations where the advancement of a qualified person within the hierarchy of an organization is stopped at a lower level because of some form of discrimination, most commonly racism or sexism. It is believed to be unofficial, invisible barrier that prevents women and minorities from advancing in business or barrier to career advancement into upper level management positions because of discrimination based on person's gender, age, race, ethnicity or sexual preference. It is also defined as an unacknowledged discriminatory barrier that prevents women and minorities from rising to positions of power or responsibility. Over the years the proportion of women in the middle and the lower level management position has increased considerable, but the proportion of women in the top management position is lessor. It is seen that women move ahead in the hierarchy level s until they encounter a glass ceiling that prevents their possibility of reaching top level management positions [4]. Studies have shown that women are inadequately represented in the executive leadership and governance position. It is said that women confront two types of 
concerns in the form of social scenario and the corporate scenario. Though women are considered to have marched purposefully towards the direction of equality towards achieving higher senior position, the basic fact that women do not share equal participation and representation the these roles remain the same. Complex, unseen barriers limit the growth of women who desire to climb into the positions of authority and power [5].

\section{Methodology of the Study}

This study is descriptive in nature. The researcher has collected the information from the data bases published by government approved agencies and also other secondary information from newspapers, articles, journals etc.

\section{Indian Constitution \& Equality for Women}

The constitution of India in its preamble, Fundamental rights and duties and directive principles has treasured the principle of Gender equity. Indian constitution not only manifests equality for women but also authorizes the state to embrace measures in favour of women. Plans and programmes, certain developmental policies are developed for women empowerment in different areas. International conventions and human right instruments towards achieving equal rights of women have been officially confirmed and organised. Noted important among it is the convention on elimination of all forms of Discrimination against Women (CEDAW) IN 1993)[6].

\section{(a) The Convention on the Elimination of All Forms of Discrimination against Women (CEDAW):}

The Convention on the Elimination of All Forms of Discrimination against Women (CEDAW), adopted by the UN General Assembly, is considered as an international bill for empowering the rights of women. It has a preamble and 30 articles that strengthens the idea of the discrimination against women and sets up a scheme to curb such discrimination. This convention defines discrimination against women as any form of exclusion, distinction and restriction done with the purpose of weakening and damaging the recognition enjoyed by women, irrespective of their marital status, on the basis of equality of men and women and fundamental freedom in economic, political, civil, cultural or any other area. The highlighting point of this convention is that it provides the base for perceiving the equality between men and women through ensuring and safeguarding the equal access and opportunities of women in public and political life. This also ensures women the right to vote and even the chance to stand for election, participation in education, employment and health. To ensure that the women will enjoy their human rights and fundamental freedom, state parties will take appropriate legislation and temporary measures. This is the only treaty which guarantees the rights of women and hits the influential forces of culture and tradition that shapes gender roles and family relations [6].

Indian constitution along with providing equality to women has also ensured measures thus reducing the unfavourable situation faced by them. This has made the economic, social, education and political sectors more advantageous for the entry of women. Fundamental rights provide equality and protection by law, but more importantly it prohibits discrimination of any citizen on the basis of sex, race, religion or birthplace. It also guarantees equality of opportunity to all the citizens with regards to employment [6]. This can be considered to be the weapon which the country has given to women to find their place in the society. 
IRA-International Journal of Management \& Social Sciences

Table 1: Privileges and initiatives for women under Constitution of India

\begin{tabular}{|c|c|c|}
\hline ARTICLES & \multicolumn{2}{|c|}{ PRIVILEGES } \\
\hline Article 14 & \multicolumn{2}{|c|}{ Women have the privilege for equality before law } \\
\hline Article 15 (i) & \multicolumn{2}{|c|}{$\begin{array}{l}\text { There is no discrimination against any citizen in the state on the basis } \\
\text { of race, religion, caste, sex or birth place. }\end{array}$} \\
\hline Article 15 (3) & \multicolumn{2}{|c|}{ Special provision for women and children in the state } \\
\hline Article 16 & \multicolumn{2}{|c|}{$\begin{array}{l}\text { Equal opportunity in terms of employment or appointment to any } \\
\text { office under the state for all the citizens. }\end{array}$} \\
\hline Article 39(d) & \multicolumn{2}{|c|}{$\begin{array}{l}\text { Direction by the state towards achieving equal pay for equal work for } \\
\text { both men and women. }\end{array}$} \\
\hline Arti & \multicolumn{2}{|c|}{$\begin{array}{l}\text { Direction by the state regarding the conditions of work and maternity } \\
\text { relief which is just and humane. }\end{array}$} \\
\hline Artic & \multicolumn{2}{|c|}{$\begin{array}{l}\text { Promotion of economic and educational interest of the weaker section } \\
\text { and also protection from exploitation and social injustice. }\end{array}$} \\
\hline $243 \mathrm{D}(3)$ & \multicolumn{2}{|c|}{$\begin{array}{l}\text { Not less than } 1 / 3^{\text {rd }} \text { of the total numbers of seats which are to be } \\
\text { occupied by direct election are reserved for women. }\end{array}$} \\
\hline 243 D (4) & \multicolumn{2}{|c|}{$\begin{array}{l}\text { Not less than } 1 / 3^{\text {rd }} \text { of the total number of chairpersons offices in the } \\
\text { Panchayat are reserved for women. }\end{array}$} \\
\hline $243 \mathrm{~T} \mathrm{(3)}$ & \multicolumn{2}{|c|}{$\begin{array}{l}\text { Not less than } 1 / 3^{\text {rd }} \text { of the total seats in municipality to be filled by } \\
\text { direct election are reserved for women. }\end{array}$} \\
\hline $\begin{array}{l}\text { INITIATIVES TAKEN } \\
\text { BY GOVERNMENT }\end{array}$ & YEAR & PROVISION \\
\hline $\begin{array}{l}\text { National Commission for } \\
\text { Women }\end{array}$ & 1992 & $\begin{array}{l}\text { Government of India incorporated this statutory body to } \\
\text { study and monitor matters relating to the legal safety } \\
\text { provisions and constitutional matters towards women and } \\
\text { make amendments whenever necessary. }\end{array}$ \\
\hline $\begin{array}{l}\text { Reservation in Local } \\
\text { self-Government }\end{array}$ & 1992 & $\begin{array}{l}\text { This reservation ensures } 1 / 3^{\text {rd }} \text { of the total seats for women } \\
\text { in the elected offices of local bodies of rural and urban } \\
\text { areas. This was passed in the } 73^{\text {rd }} \text { amendment of } \\
\text { constitutional amendment act. }\end{array}$ \\
\hline $\begin{array}{l}\text { The National Plan of } \\
\text { Action for the Girl Child }\end{array}$ & $\begin{array}{l}1991- \\
2000\end{array}$ & $\begin{array}{l}\text { This plan is towards the girl child, to ensure the survival, } \\
\text { development and protection for the better future. }\end{array}$ \\
\hline $\begin{array}{l}\text { National Policy for the } \\
\text { Empowerment of } \\
\text { Women }\end{array}$ & 2001 & $\begin{array}{l}\text { Department of women and child development, Human } \\
\text { resource Development has come up with this policy to } \\
\text { bring development, empowerment and advancement of } \\
\text { women. }\end{array}$ \\
\hline
\end{tabular}

Source: Ministry of statistics and programme implementation

The above table 1 shows the privileges enjoyed by women and also the initiatives taken by government as in the constitution of India. Articles above highlight the equal opportunity, equal pay in terms of employment or appointment for all the citizens. It can be clearly seen that there is special provision in the state for women and children apart from conditions of work and maternity requirements. Articles also stress on promotion of economic and education requirements of weaker section. It also provides for protection from social injustice and exploitation. This is a boon for the women in India to climb up in the career ladder. Though women have realized their potential and have entered into all the domains. The question here is the ratio of women in relation to men in spite of the reservation and privileges given by the constitution. 


\section{Authoritative Key Positions held by women in politics}

Political participation here is not just related to the right the vote but also participation of women in decision making process, political awareness and political activism. Participation of women in Election campaigning and voting turnout has increased but women seem to be under represented in political parties and in legislative bodies both at the national level and also the state level [7]. Constitution of India in 1952 promised "to secure to all its citizens justice, social, economic and political and "equality of status and opportunity' [8]. In spite of the promise proclaimed by the constitution, women in India continue to be under represented in politics [7]. In this paper the researcher has made an attempt to study the authoritative key positions occupied by women at the union executive level, central and the Karnataka state ministries and also the legislative bodies.

(a) Presidents, Vice Presidents and Prime ministers and cabinet secretaries:

Union executive includes President, the Vice President and the Council of Ministers. As per the Article 74(1) the Prime Minister and his Council of Ministers advise and aid the President of India. The Cabinet Secretary is the highest position in the Indian Administrative service (IAS). Cabinet Secretariat is under the direct charge of Prime Minister. This position is responsible for the administration of the Government of India rules, 1961 (Transaction of Business) and the Government of India rules 1961 (Allocation of Business). Cabinet Secretary helps in smooth business transactions in ministries and government departments by maintaining steadiness and perseverance to these rules. Inter departmental coordination, ruling out the differences between ministries if any and also helps in maintaining harmony in the form of instrumentality of the secretaries ad-hoc committees. This also encourages the promotion of the new policies initiatives [9].

Table 2: List of Presidents, Vice Presidents, Prime ministers of India and gender balance since 1950

\begin{tabular}{|l|l|l|l|l|l|}
\hline $\begin{array}{l}\text { SL. } \\
\text { NO }\end{array}$ & $\begin{array}{l}\text { POSITIONS } \\
\text { SINCE 1950 }\end{array}$ & TOTAL & MALE & FEMALE & $\begin{array}{l}\text { OF FEMALE } \\
\text { REPRESENTATIVES }\end{array}$ \\
\hline 01 & Presidents* & 16 & 15 & 01 & $6.25 \%$ \\
\hline 02 & Vice Presidents* & 12 & 12 & Nil & $0 \%$ \\
\hline 03 & Prime Ministers* & 19 & 17 & $\begin{array}{l}2 \text { (Smt. Indira } \\
\text { Gandhi was } \\
\text { elected twice) }\end{array}$ & $10.5 \%$ \\
\hline 04 & $\begin{array}{l}\text { Cabinet } \\
\text { Secretaries** }\end{array}$ & 31 & 31 & Nil & $0 \%$ \\
\hline \multicolumn{2}{|l|}{ TOTAL } & 78 & 75 & 03 & $3.85 \%$ \\
\hline
\end{tabular}

Source: *www.gkduniya.com/president-prime-minister-india, ${ }^{*} *$ Cabinet Secretariat, Government of India

Table 2 depicts the gender wise classification of Presidents, Vice Presidents, Prime Ministers and Cabinet Secretaries ever since the formation of the government. Out of four categories that make the total of 78 positions, only 03 positions have been occupied by women. This makes the total percentage as just $3.85 \%$. Ever since India became Independent, India has seen the service of the Presidents, Vice Presidents and Prime Ministers and the Cabinet Secretaries towards the growth and development of the nation. Out of total 16 Presidents only 1 president was a woman. This makes the percentage to be just $6.25 \%$.Out of total 12 Vice Presidents all vice presidents were male and no women vice presidents have occupied this position. $0 \%$ is the figure which indicates that women have been underrepresented here. Among the 19 Prime ministers late Indira Gandhi was the only woman elected twice. It is a sad situation to see that only one woman(elected twice) 
has occupied this honorable post. The charge of the highest position of cabinet secretariat in India was first taken in 1950. Since then till date 31 people have occupied this position. As per the data published by cabinet secretariat, Government of India the number of women occupying this position is Nil. This data is something that makes one read the figures again. Out of 31 positions all the positions were held by men. Here it can be observed except for Late. Indira Gandhi and Smt. Prathiba Patil, women are yet to occupy this high position.

\section{(b) Cabinet of India:}

The cabinet of India comprises of Prime minister and his council of Ministers. The council of ministers main function is to advise and help the President in exercising his power and this is headed by the Prime minister and advised by the Cabinet Secretary. Other ministers are union Cabinet Ministers and Ministers of State (Independent charge), Minister of State and Deputy Ministers. The present council of Ministers was announced on 12.07.2016 [10]. The following table shows the total number of male and female cabinet ministers, ministers of state (Independent charge), ministers of state, chief ministers of all states and the governors of all states and the union territories.

Table 3: Ratio of Cabinet Ministers, minister of state( independent charge), ministers of state, Chief ministers(All states) and Governors (All states and UT)

\begin{tabular}{|l|l|l|l|l|l|}
\hline SL.NO & CATEGORY & TOTAL & MALE & FEMALE & $\begin{array}{l}\text { \% OF } \\
\text { REPRESELTATIVES }\end{array}$ \\
\hline 01 & Cabinet ministers* & $\mathbf{2 6}$ & $\mathbf{2 1}$ & $\mathbf{0 5}$ & $\mathbf{1 9 . 2 \%}$ \\
\hline 02 & $\begin{array}{l}\text { Ministers of state } \\
\text { (Independent charge)* }\end{array}$ & 13 & 12 & 01 & $7.7 \%$ \\
\hline 03 & $\begin{array}{l}\text { Ministers of state* } \\
\text { Chief ministers (All } \\
\text { states)** }\end{array}$ & 29 & 25 & 04 & $13.8 \%$ \\
\hline 04 & $\begin{array}{l}\text { Governors (All states and } \\
\text { UT) }\end{array}$ & 36 & 32 & 04 & $11.1 \%$ \\
\hline 05 & 140 & 123 & 17 & $12.1 \%$ \\
\hline
\end{tabular}

Source:*Cabinet secretariat, Government of India ** Chief Ministers India.gov.in

Table 3 depicts the gender wise classification of Cabinet Ministers, Minister of State (Independent charge), Ministers of State, Chief Ministers of all states and the Governors of all states and the union territories. Total percentage of women representatives here is just $12.1 \%$. Out of the total 140 positions majority of 123 positions are held by men and only 17 women have got the opportunity of occupying these positions. This means at present we have just 05 women cabinet ministers out of 26. Out of 13 ministers of state (Independent charge) only 01 is a woman. Out of 36 ministers of state only 03 are women and 33 are men. India being a vast nation comprising 29 states having 29 Chief Ministers, only 04 are women. Looking at the figures of Governors of all sates and union territories, out of total 36 only four are women. The question that arises here is the reason why the representation of women is so low. 
Table 4: Gender wise classification of cabinet Ministers and minister of state (independent charge) and ministers of state in every state

\begin{tabular}{|c|c|c|c|c|c|}
\hline SI.No & $\begin{array}{l}\text { STATE WISE CABINET } \\
\text { MINISTERS AND MINISTERS } \\
\text { OF STATE }\end{array}$ & TOTAL & $\begin{array}{l}\text { MAL } \\
\text { E }\end{array}$ & $\begin{array}{l}\text { FEMAL } \\
\text { E }\end{array}$ & $\begin{array}{l}\% \text { of } \text { Female } \\
\text { Representative } \\
\text { S }\end{array}$ \\
\hline 01 & Andra Pradesh & 19 & 16 & 03 & $15.8 \%$ \\
\hline 02 & Arunachal Pradesh & 11 & 11 & Nil & $0 \%$ \\
\hline 03 & Assam & 13 & 10 & 03 & $23.1 \%$ \\
\hline 04 & Bihar & 28 & 26 & 02 & $7.1 \%$ \\
\hline 05 & Chattisgarh & 12 & 11 & 01 & $8.3 \%$ \\
\hline 06 & Goa & 11 & 10 & 01 & $9.1 \%$ \\
\hline 07 & Gujrath & 24 & 23 & 01 & $4.4 \%$ \\
\hline 08 & Haryana & 17 & 16 & 01 & $5.6 \%$ \\
\hline 09 & Himachal Pradesh & 11 & 10 & 01 & $9.1 \%$ \\
\hline 10 & Jammu and Kashmir & 22 & 20 & 02 & $9.1 \%$ \\
\hline 11 & Jharkand & 10 & 08 & 02 & $20 \%$ \\
\hline 12 & Karnataka & 33 & 32 & 01 & $3.0 \%$ \\
\hline 13 & Kerala & 18 & 16 & 02 & $11.1 \%$ \\
\hline 14 & Madhya Pradesh & 20 & 16 & 04 & $20 \%$ \\
\hline 15 & Maharashtra & 37 & 36 & 01 & $2.7 \%$ \\
\hline 16 & Manipur & 11 & 10 & 01 & $9.1 \%$ \\
\hline 17 & Meghalaya & 11 & 08 & 03 & $27.3 \%$ \\
\hline 18 & Mizoram & 11 & 11 & Nil & $0 \%$ \\
\hline 19 & Nagaland & 10 & 10 & Nil & $0 \%$ \\
\hline 20 & Odisha & 25 & 22 & 03 & $12 \%$ \\
\hline 21 & Punjab & 17 & 17 & Nil & $0 \%$ \\
\hline 22 & Rajasthan & 13 & 12 & 01 & $7.7 \%$ \\
\hline 23 & Sikkim & 11 & 11 & Nil & $0 \%$ \\
\hline 24 & Tamil Nadu & 28 & 26 & 02 & $7.1 \%$ \\
\hline 25 & Telangana & 17 & 17 & Nil & $0 \%$ \\
\hline 26 & Tripura & 11 & 10 & 01 & $9.1 \%$ \\
\hline 27 & Uttar Pradesh & 56 & 55 & 01 & $1.8 \%$ \\
\hline 28 & Uttarkhand & 09 & 08 & 01 & $11.1 \%$ \\
\hline 29 & West Bengal & 41 & 38 & 03 & $7.3 \%$ \\
\hline \multicolumn{2}{|c|}{ TOTAL } & 557 & 516 & 41 & $7.4 \%$ \\
\hline
\end{tabular}

Source:www.newincept.com as on 25.10.2016 @ 11.13am

Table 4 shows the Gender wise classification of Cabinet Ministers and Minister of State (Independent charge) and Ministers of State in every state of India. Here one can see that in Arunachal Pradesh, Mizoram, Nagaland, Punjab, Sikkim and Telangana the percentage of women representatives is Nil. Underrepresentation of women here is a matter of concern.Sates like Meghalaya with $27.3 \%$ of women ministers and Assam with $23.1 \%$ seems to have better representation from women in politics. Overall in the entire nation of 29 states, out of 557 cabinet ministers, ministers of state and ministers of state(independent charge) there are only 41 women, making it $7.4 \%$ which is a clear indication that women are yet to set their footprints in this sector. 
(c) Parliament of India:

The Parliament of India is the apex legislative body of India. It includes the two houses i.e. LokSabha and Rajya Sabha. The president is the head of this legislative body.

Table 5 : Gender wise classification of LokSabha members in every state and Union Territories

\begin{tabular}{|c|c|c|c|c|c|}
\hline SL.NO & $\begin{array}{l}\text { STATE WISE LOK } \\
\text { SABHA MEMBERS }\end{array}$ & TOTAL & MALE & FEMALE & $\begin{array}{lcr}\% & \text { OF } & \text { FEMALE } \\
\text { REPRESENTATIVES }\end{array}$ \\
\hline 01 & Andra Pradesh & 25 & 23 & 02 & $8 \%$ \\
\hline 02 & Arunachal Pradesh & 02 & 02 & Nil & $0 \%$ \\
\hline 03 & Assam & 13 & 11 & 02 & $15.4 \%$ \\
\hline 04 & Bihar & 40 & 37 & 03 & $7.5 \%$ \\
\hline 05 & Chattisgarh & 11 & 10 & 01 & $9.1 \%$ \\
\hline 06 & Goa & 02 & 02 & Nil & $0 \%$ \\
\hline 07 & Gujrath & 26 & 21 & 05 & $19.2 \%$ \\
\hline 08 & Haryana & 10 & 10 & Nil & $0 \%$ \\
\hline 09 & Himachal Pradesh & 04 & 04 & Nil & $0 \%$ \\
\hline 10 & Jammu and Kashmir & 04 & 04 & Nil & $0 \%$ \\
\hline 11 & Jharkand & 14 & 14 & Nil & $0 \%$ \\
\hline 12 & Karnataka & 28 & 27 & 01 & $3.6 \%$ \\
\hline 13 & Kerala & 20 & 19 & 01 & $5 \%$ \\
\hline 14 & Madhya Pradesh & 28 & 23 & 05 & $17.9 \%$ \\
\hline 15 & Maharashtra & 48 & 42 & 06 & $12.5 \%$ \\
\hline 16 & Manipur & 02 & 02 & Nil & $0 \%$ \\
\hline 17 & Meghalaya & 02 & 02 & Nil & $0 \%$ \\
\hline 18 & Mizoram & 01 & 01 & Nil & $0 \%$ \\
\hline 19 & Nagaland & 01 & 01 & Nil & $0 \%$ \\
\hline 20 & Odisha & 21 & 18 & 03 & $14.3 \%$ \\
\hline 21 & Punjab & 13 & 12 & 01 & $7.7 \%$ \\
\hline 22 & Rajasthan & 25 & 24 & 01 & $4 \%$ \\
\hline 23 & Sikkim & 01 & 01 & Nil & $0 \%$ \\
\hline 24 & Tamil Nadu & 39 & 35 & 04 & $10.3 \%$ \\
\hline 25 & Telangana & 17 & 16 & 01 & $5.9 \%$ \\
\hline 26 & Tripura & 02 & 02 & Nil & $0 \%$ \\
\hline 27 & Uttar Pradesh & 80 & 67 & 13 & $16.3 \%$ \\
\hline 28 & Uttarkhand & 05 & 04 & 01 & $20 \%$ \\
\hline 29 & West Bengal & 40 & 28 & 12 & $30 \%$ \\
\hline SI. No & \begin{tabular}{lrr} 
UNION & \multicolumn{2}{c}{ TERRITORY } \\
WISE & LOK & SABHA \\
MEMBERS &
\end{tabular} & & & & \\
\hline 1 & Andaman & 01 & 01 & Nil & $0 \%$ \\
\hline 2 & Chandigarh & 01 & Nil & 01 & $100 \%$ \\
\hline 3 & Daman & 01 & 01 & Nil & $0 \%$ \\
\hline 4 & NCT of Delhi & 07 & 06 & 01 & $14.3 \%$ \\
\hline 5 & Dadra \& Nagar Haveli & 01 & 01 & Nil & $0 \%$ \\
\hline 6 & Lakshadweep & 01 & 01 & Nil & $0 \%$ \\
\hline 7 & Puducherry & 01 & 01 & Nil & $0 \%$ \\
\hline \multicolumn{2}{|l|}{ TOTAL } & 537 & 473 & 64 & $11.98 \%$ \\
\hline
\end{tabular}

Source: Parliament of India- Loksabha 
Table 5 shows gender wise classification of LokSabha members in every state and Union Territories of India. Out of the total 537 members, only 64 members are women making it 11.98\%. Remaining $88.02 \%$ are male members. To highlight this situation, states like Arunachal Pradesh, Goa, Haryana, Himachal Pradesh, Jammu \& Kashmir, Jharkhand, Manipur, Meghalaya, Mizoram, Nagaland, Sikkim, Tripura and Union territories like Andaman, Daman, Dadra and Nagar Haveli, Lakshadweep and Puducherry have Nil women LokSabha Members.

Table 6 : Gender wise classification of Rajya Sabha members in every state and Union Territories

\begin{tabular}{|c|c|c|c|c|c|}
\hline S.NO & $\begin{array}{l}\text { STATE WISE RAJYA } \\
\text { SABHA MEMBERS }\end{array}$ & TOTAL & MALE & FEMALE & $\begin{array}{lcr}\% & \text { OF } & \text { FEMALE } \\
\text { REPRESENTATIVES }\end{array}$ \\
\hline 01 & Nominated & 12 & 08 & 04 & $33.3 \%$ \\
\hline 02 & Andra Pradesh & 11 & 09 & 02 & $18.2 \%$ \\
\hline 03 & Arunachal Pradesh & 01 & 01 & Nil & $0 \%$ \\
\hline 04 & Assam & 07 & 06 & 01 & $14.3 \%$ \\
\hline 05 & Bihar & 16 & 14 & 02 & $12.5 \%$ \\
\hline 06 & Chattisgarh & 05 & 04 & 01 & $20 \%$ \\
\hline 07 & Goa & 01 & 01 & Nil & $0 \%$ \\
\hline 08 & Gujrath & 11 & 10 & 01 & $9.1 \%$ \\
\hline 09 & Haryana & 05 & 04 & 01 & $20 \%$ \\
\hline 10 & Himachal Pradesh & 03 & 02 & 01 & $33.3 \%$ \\
\hline 11 & Jammu and Kashmir & 04 & 04 & Nil & $0 \%$ \\
\hline 12 & Jharkand & 06 & 06 & Nil & $0 \%$ \\
\hline 13 & Karnataka & 12 & 11 & 01 & $8.3 \%$ \\
\hline 14 & Kerala & 9 & 9 & Nil & $0 \%$ \\
\hline 15 & Madhya Pradesh & 11 & 11 & Nil & $0 \%$ \\
\hline 16 & Maharashtra & 19 & 17 & 02 & $10.5 \%$ \\
\hline 17 & Manipur & 01 & 01 & Nil & $0 \%$ \\
\hline 18 & Meghalaya & 01 & Nil & 01 & $100 \%$ \\
\hline 19 & Mizoram & 01 & 01 & Nil & $0 \%$ \\
\hline 20 & Nagaland & 01 & 01 & Nil & $0 \%$ \\
\hline 21 & Odisha & 10 & 09 & 01 & $10 \%$ \\
\hline 22 & Punjab & 07 & 06 & 01 & $07 \%$ \\
\hline 23 & Rajasthan & 10 & 10 & Nil & $0 \%$ \\
\hline 24 & Sikkim & 1 & 1 & Nil & $0 \%$ \\
\hline 25 & Tamil Nadu & 18 & 15 & 03 & $16.7 \%$ \\
\hline 26 & Telangana & 07 & 07 & Nil & $0 \%$ \\
\hline 27 & Tripura & 01 & Nil & 01 & $100 \%$ \\
\hline 28 & Uttar Pradesh & 31 & 28 & 03 & $9.8 \%$ \\
\hline 29 & Uttarkhand & 03 & 03 & Nil & $0 \%$ \\
\hline 30 & West Bengal & 16 & 15 & 01 & $6.3 \%$ \\
\hline $\begin{array}{l}\text { Sl. } \\
\text { No }\end{array}$ & $\begin{array}{lr}\text { UNION } & \text { TERRITORY } \\
\text { WISE RAJYA SABHA } \\
\text { MEMBERS }\end{array}$ & & & & \\
\hline 01 & NCT of Delhi & 03 & 03 & Nil & $0 \%$ \\
\hline 02 & Puducherry & 01 & 01 & Nil & $0 \%$ \\
\hline \multicolumn{2}{|c|}{ TOTAL } & 245 & 218 & 27 & $11.02 \%$ \\
\hline
\end{tabular}

Source: Rajya Sabha secretariat 
Table 6 depicts the Gender wise classification of Rajya Sabha members in every state and Union Territories of India. Total Rajya Sabha members are 245 out of which only 27 are women members. Merely $11.02 \%$ of women occupy the seats in Rajya Sabha. Arunachal Pradesh, Goa, Jammu \& Kashmir, Jharkhand, Kerala, Madhya Pradesh, Manipur, Mizoram, Nagaland, Rajasthan, Sikkim, Telangana, Uttarakhand and union territories like NCT of Delhi and Puducherry have no women Rajya Sabha members.

\section{(d) Karnataka State Government and Gender Balance:}

When one refers to the political participation of women in the state of Karnataka, the government is headed by the governor as the head of the state. He appoints the Chief Minister and the Council of Ministers. Karnataka's Cabinet Ministry led by Chief Minister of the state comprising of Cabinet ministers, Ministers of State and Deputy Ministers. Details of the Karnataka government since Independence was collected and evaluated to see the number of women chief ministers [11]. The analysis report is as follows:

Table 7 : List of Governors of Karnataka since 1956

\begin{tabular}{|l|l|l|l|l|l|}
\hline SL.NO & CATEGORY & TOTAL & MALE & FEMALE & $\begin{array}{l}\% \text { OF FEMALE } \\
\text { REPRESENTATIV } \\
\text { ES }\end{array}$ \\
\hline 01 & Governors* & 18 & 17 & 01 & $5.6 \%$ \\
\hline 02 & Chief Minister** & 30 & 30 & 0 & NIL \\
\hline Total & 48 & 47 & 01 & $2.1 \%$ \\
\hline
\end{tabular}

Source: karnataka.com/govt/governor*/ list-of-chief-ministers**

Above Table 7 exhibits the postions held as Governors of Karnataka since 1956. It can be seen that out of 18 Governors only 01 was a woman. Out of the total chief ministers not a single women has served as the chief minister of Karnataka. Women empowerment is spoken in every sphere of life but the data above shows the number of women Chief Ministers the state of Karnataka is Nil.

Table 8 : Cabinet Ministers and Ministers of state of Karnataka

\begin{tabular}{|l|l|l|l|l|l|}
\hline $\begin{array}{l}\text { SL. } \\
\text { NO }\end{array}$ & CATEGORY & TOTAL & MALE & $\begin{array}{l}\text { FEMAL } \\
\text { E }\end{array}$ & $\begin{array}{l}\% \text { OF FEMALE } \\
\text { REPRESENTATIVES }\end{array}$ \\
\hline 01 & Cabinet Ministers & 29 & 28 & 01 & $3.5 \%$ \\
\hline 22 & Minister of State & 04 & 04 & Nil & $0 \%$ \\
\hline Total & 33 & 32 & 01 & $3.03 \%$ \\
\hline
\end{tabular}

Source: karnataka.com/govt

Table 8 depicts the Cabinet ministers and ministers of state of Karnataka. Out of total 33 council of ministers only $01(3.03 \%)$. There is only 01 cabinet minister and there are no women ministers of state. This means the participation of women in inadequate.

\section{Conditions required for women to occupy key positions:}

The remedy can be mass awareness programmes with regards to positive discrimination for women and gender equity, promotion and increase in the number of women at the village level into public domain, organizing various training progammes for skill up gradation, providing political education to women especially rural women through voluntary and government agencies to create awareness about the role and responsibility of women in the decision making process. It is seen that women are underrepresented in the government bodies like Legislature, executive and judiciary. Self Help groups have a major role in women empowerment at the domestic as well as 
the society level. The collective actions taken bring in the traits like strength, leadership and other threat. This will help the women to realize their potential which will bring the wellbeing and development of women. Micro credit can be a solution to reduce rural poverty and speed up the socio -economic development in women. Nairobi Conference and the non-aligned meet of 1985 have identified the issues related to the women's political participation, their problems and also the strategies that favour the empowerment of women. Participation of women in political decision making seems to be a big challenge due to illiteracy, less political knowledge about the working system of the women in government and also lack of political education [12].

\section{Conclusion:}

India is a developing economy. Becoming a developed nation can become a reality only when all its citizens' potential is utilized fully. If women are suppressed from participation especially in high public leadership then its impact on the nation can be undesirable. In the above study the researcher has observed the participation of women in authoritative key positions which involves decision making is low. One cannot deny that women are not involved at all; but the number is only a handful. Women have shown their expertise in lower positions. The constraints and the factors that prevent women from occupying these high authoritative positions can be a subject of study by itself. Generally one can point out the prevailing traditional and cultural role of women in our society, family responsibilities; stereotype thinking is the reason for women backwardness. Women in $21^{\text {st }}$ century perform multiple roles of managing family as well as work. Work life balance is a challenge faced by working women. Even after 69 years of independence women seem $t$ o have been struggling to enter the arena of decision making and political authority. $73^{\text {rd }}$ and $74^{\text {th }}$ amendment act though have provided entry at the grass root level, the representation of women in the parliament and state legislatures seems to be poor. Unless women become aware of their rights and duties and are given powers to prove their efficiency, women will remain underrepresented even after reservation. Building awareness among girls at the early age can boost up the confidence helping them to understand and realize their potentialities.

\section{References}

[1] Adair C. K. (1999). Cracking the glass ceiling: Factors influencing women's attainment of senior executive positions. USA Dissertation .com, ISBN: 1-58112-064-8.

[2] Hymowitz C and Schellhardt, T. D. (1986). The glass ceiling: Why women can't seem to break the invisible barrier that block them from the top jobs. The wall street journal, March 2014.

[3] www.theglasshammer.com/2009/04/09/the-glass-ceiling-who-said-that. The glass ceiling: who said that?. Retrieved on 21.10.2016 @ 4.22 pm.

[4] Powell, G.N. (1999). Reflections on the glass ceiling in G.N Powell (Ed). Handbook of gender and work, Thousand oaks, CA: Sage publication, 325-345.

[5] Dee- Ann Schwanke (2013). Barriers for women to positions of power: How societal and corporate structures, perceptions of leadership and discrimination restrict women's advancement to authority. Earth common journal, 3(2), 1-2.

[6] www.un.org/womenwatch/daw/cedaw/cedaw.htm. Convention on the elimination of all forms of discriminations against women. Retrieved on 21.10.2016.

[7] Praveeen Rai (2011). Electoral participation of women in India: Key determinants and barriers. Economic and political weekly, 16(3), 47-55. 
[8] BauDurga Das (1998). Introduction to the constitution of India. Prentice- Hall of India, New Delhi.

[9] www.mospi.nic.in/Mospi_New/upload/man_and_women/ConstitutionalRights.pdf. Ministry of statistics and programme implementation. Retrieved on 1.10.2016.

[10] www.cabsec.nic.in/about_cabinet.php. Cabinet Secretariat, Government of India. Retrieved on 21.07.2016.

[11] www.karnataka.com/govt/cabinet-ministry. Cabinet ministry in Karnataka. Retrieved on 20.10.2016.

[12] Pradeep M. D. \& Deeksha (2016). Multi dimensional approach for empowerment - effective strategies to face problems and challenges of Women in India. International Journal of Scientific Research and Modern Education (IJSRME), 1(1), 744-755.

[13] www.womenshistory.about.com/od/work/g/glass_ceiling.htm. Glass ceiling for women. Retrieved on July 142016 @ 3:13 pm.

[14] www.cabsec.nic.in/showpdf.php?type=council_cabinet_cabinetministers Cabinet ministers of India. Retrieved on 21.7.2016.

[15] www.newincept.com/karnataka/council-of-ministers-of-karnataka.htmlretrieved on 24.10.2016@12.05 pm.

[16] www.loksabha.nic.in.Parliament of india-LokSabha Retrieved on 28.10.2016 @ 12.46 pm.

[17] www.rajyasabha.nic.in/rsnew/council_state/council_state.asp. Rajya Sabah secretariat Retrieved on 28.10.2016. 